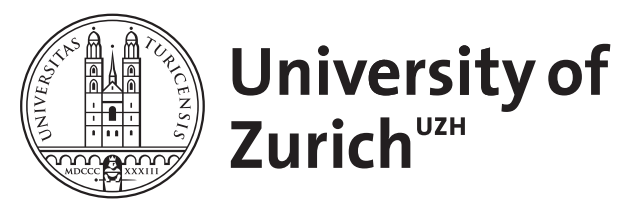

\title{
Chapter 9: Pragmatics and Discourse
}

\author{
Jucker, Andreas H
}

\begin{abstract}
Pragmatics studies the processes of language use, while discourse analysis is devoted to its product, i.e. discourse. Pragmatics can be understood in a narrow sense focussing on cognitive-inferential aspects of information processing, and it can be understood in a wider sense in which it also includes social aspects of interaction. In historical pragmatics, the former conceptualization lies behind work on pragmatic explanations in language change, while the latter conceptualization studies earlier language use from a social and interactional perspective, including such aspects as inserts (e.g. interjections and discourse markers), speech acts, and terms of address. Discourse, as the product of language use, can be seen as a stretch of conversation (dialogue) or as a domain of communication. In the former conceptualization, research focuses on the structural properties of the dialogue, and in the latter, it deals with the linguistic practices pertaining to particular fields of knowledge or interaction, e.g. courtroom discourse, the discourse of science, and news discourse.
\end{abstract}

Posted at the Zurich Open Repository and Archive, University of Zurich

ZORA URL: https://doi.org/10.5167/uzh-140820

Book Section

Published Version

Originally published at:

Jucker, Andreas H (2017). Chapter 9: Pragmatics and Discourse. In: Brinton, Laurel J; Bergs, Alexaner. The History of English/Historical Outlines from Sound to Text. Berlin: De Gruyter, 165-184. 


\title{
Pragmatics and Discourse
}

\author{
1 Introduction -165 \\ 2 Pragmatic explanations in language change -168 \\ 3 Pragmatics as the study of performance phenomena $-\mathbf{1 7 0}$ \\ 4 Discourse as dialogue -174 \\ 5 Discourse as a domain of communication -176 \\ 6 Summary and outlook $-\mathbf{1 7 9}$ \\ 7 References $-\mathbf{1 8 0}$
}

\begin{abstract}
Pragmatics studies the processes of language use, while discourse analysis is devoted to its product, i.e. discourse. Pragmatics can be understood in a narrow sense focussing on cognitive-inferential aspects of information processing, and it can be understood in a wider sense in which it also includes social aspects of interaction. In historical pragmatics, the former conceptualization lies behind work on pragmatic explanations in language change, while the latter conceptualization studies earlier language use from a social and interactional perspective, including such aspects as inserts (e.g. interjections and discourse markers), speech acts, and terms of address. Discourse, as the product of language use, can be seen as a stretch of conversation (dialogue) or as a domain of communication. In the former conceptualization, research focuses on the structural properties of the dialogue, and in the latter, it deals with the linguistic practices pertaining to particular fields of knowledge or interaction, e.g. courtroom discourse, the discourse of science, and news discourse.
\end{abstract}

\section{Introduction}

In a very general sense pragmatics can be defined as the study of language use, while discourse analysis, in an equally general sense, can be defined as the analysis of the result of human communication, viz. discourse.

Andreas H. Jucker: Zürich (Switzerland) 
It has been suggested that discourse analysis is more text-centered, more static, more interested in product (in the well-formedness of texts), while pragmatics is more usercentred, more dynamic, more interested in the process of text production. Discourse analysis is frequently equated with conversational analysis, and pragmatics with speech act theory. It would seem difficult to distinguish the two with any conviction, however (Brinton 2001: 139).

There is certainly a great deal of overlap between the two fields. A large range of topics can be dealt with under either heading. Speech acts, such as greetings and farewells, or discourse markers, such as well, so, or you know have both interactional (pragmatic) functions and text-structuring or discourse functions.

As a field of study, pragmatics has grown very considerably over the last thirty years or so. Traditionally, linguists were mainly concerned with an analysis of language structure at the levels of phonology, morphology, and syntax, but with the pragmatic turn in the late 1970s and early 1980s some of the interest shifted from the structure of language to the language user. At the beginning of this development, pragmatics was often seen as the ragbag of linguistic description (see Mey 1998: 716). As such it covered performance phenomena that could not be handled at the traditional levels of linguistic description, such as speech acts, conversational implicature, deixis, and politeness, but also the structure of conversations.

On the other hand, even in the early days of pragmatics, the discipline was also seen as a perspective. As such it was not a level of linguistic description but a different way of analyzing language. Language was not seen as a system of signs but as a means of communication. "Pragmatics is a perspective on any aspect of language, at any level of structure" (Verschueren 1987: 5, italics in original; see also Verschueren 1999: 2). Under the former view, pragmatics was a separate level of linguistic description, parallel to other levels, such as syntax or semantics. Under the latter view, pragmatics was a particular way of doing linguistics that could be applied to all other levels of linguistic description from phonology and morphology to syntax, semantics and, indeed, discourse.

These positions have developed into a more restricted cognitive-inferential conceptualization of pragmatics (adhered to, generally speaking, by Anglo-American researchers) and a broader socio-interactional conceptualization (common among European researchers). Cruse (2000), for instance, gives the following narrow definition of pragmatics:

For present purposes, pragmatics can be taken to be concerned with aspects of information (in the widest sense) conveyed through language which (a) are not encoded by generally accepted convention in the linguistic forms used, but which (b) none the less arise naturally out of and depend on the meanings conventionally encoded in the linguistic forms used, taken in conjunction with the context in which the forms are used (Cruse 2000: 16). 
In this conceptualization, people routinely understand more than what is explicitly communicated. They read between the lines, as it were, and this is the field of the pragmaticist. In her handbook article on historical pragmatics, Traugott (2004: 539) also takes pragmatics "to be non-literal meaning that arises in language use", and Sperber and Noveck (2004: 1) define pragmatics as "the study of how linguistic properties and contextual factors interact in the interpretation of utterances". In their view, pragmatics is not restricted to a study of implicit meanings. In fact, they are at pains to demonstrate that there are many aspects of explicit meaning that require access to contextual information for their interpretation, but they exclude the wider social issues of language use from the scope of pragmatics.

The European tradition adopts a broader, more sociologically based view of pragmatics that includes social and cultural conditions of language use. Trosborg (1994: 37), a representative of this broader European tradition, for instance, states that "sociopragmatics is concerned with the analysis of significant patterns of interaction in particular social situations and/or in particular social systems. For example, speech acts may be realized differently in different social contexts and situations as well as in different social groups within a speech community", while Blakemore, a representative of the Anglo-American tradition, finds it "misleading to include phenomena like politeness, face-saving and turn taking [...] under the general heading of pragmatics” (Blakemore 1992: 47).

The two conceptualizations of pragmatics, obviously, have consequences for the interaction of pragmatics and historical linguistics. The former conceptualization suggests a range of specific performance-related topics, while the latter suggests a specific way of investigating earlier stages of a language and its development.

The term "discourse" is perhaps even more open to different definitions. On the one hand, it can be seen as the spoken equivalent of a text. A (written) text is made up of sentences while a (spoken) discourse is made up of utterances. In this sense, the term "discourse" is more or less synonymous with the term "dialogue" (see below, Section 4). Brinton (2001: 139-140) distinguishes between three discourse analytical approaches to historical data. First, the discourse analyst may use forms, functions, and structures of discourse at historical stages of a language. She calls this approach "historical discourse analysis proper". Second, the discourse analyst may study the discourse-pragmatic factors and motivations behind language change. This approach is called "discourse-oriented historical linguistics”. And third, the discourse analyst may focus on the diachronic development of discourse functions and discourse structures over time. She calls this third approach "diachronic(ally oriented) discourse analysis".

However, the term "discourse" can also be used in a much wider sense, not just for a linguistic unit larger than utterances, but as a domain of language. In 
such a view, a discourse is a collection of linguistic practices characterized by a distinct group of people and a distinct group of genres and text types, e.g. the discourse of science, or more specifically the discourse of medical science or the discourse of modern linguistics.

In the following I shall evaluate how these conceptualizations of the terms "pragmatics" and "discourse" can be applied to the analysis of historical data and in particular to English historical data.

\section{Pragmatic explanations in language change}

In the Anglo-American conceptualization of pragmatics, pragmatics is mainly a tool to describe and explain patterns of language change. Language is a means of communication and, therefore, the communicative forces that are at work when people use language must be taken into consideration when we analyze, for instance, the syntax of a language and indeed when we analyze diachronic changes in the syntax of a language. Thus, pragmatics becomes a principle of explanation in language change. In Brinton's (2001) terminology this would be "discourse-oriented historical linguistics".

If pragmatics is seen as one level of linguistic description on a par with other levels such as phonology, morphology, syntax and semantics, it is largely restricted to non-truth-conditional aspects of language, and to aspects of language that depend on the context of utterance. Deictic elements, for instance, depend on the situation of use for their interpretation. Speech acts in their early conceptualization of doing things with words were also restricted to non-truth-conditional aspects. Speech act theory took its starting point from Austin's (1962) observation that speech acts are regularly used for purposes other than stating facts that are assessable in terms of true or false.

Meanings are not abstract entities that pertain to linguistic expressions but the result of negotiations between speaker/writer and addressee/reader, which through repetition of use - have become conventionalized. A theory of meaning change, therefore, must take into account the communicative situation of speaker/ writer and addressee/reader. Traugott and Dasher (2005), for instance, argue that it is ad-hoc negotiations of meanings that may lead to meaning change if they are invoked repeatedly until they become conventionalized in the entire speech community. They call such ad-hoc meanings "invited inferences", a term borrowed from Geis and Zwicky (1971). However, Traugott and Dasher use it in a broader sense and do not restrict it to generalized implicatures. It signals the speaker/writer's role in inviting the addressee to infer the intended ad-hoc meaning. As an example they cite the case of as/so long as (Traugott and Dasher 2005: 36-37). In Old and Middle 
English the spatial meaning ('of the same length as') co-existed with the temporal meaning ('for the same length of time as'). In some contexts, the meaning invited the conditional meaning 'provided that', as for instance in (1).

(1) wring purh linenne clað on pæt eage swa lange swa him ðearf sy. wring through linen cloth on that eye as long as him need be-subJ 'squeeze (the medication) through a linen cloth onto the eye as long as he needs.' (850-950 Lacnunga, p. 100; example, gloss, and translation from Traugott and Dasher 2005: 36, ex. 19)

The medicine is to be applied for the duration that it is needed, which invites the inference that it is to be applied only if it is needed. According to Traugott and Dasher all examples of as/so long as in Old and Middle English are either spatial or temporal, and while some allow a conditional reading, the conditional reading is never predominant. This changes in Early Modern English, when examples occur in which the invited inference of conditionality has been generalized to contexts of reasoning and cognition in which a temporal reading does not make sense or is at least not salient as in (2).

(2) They whose words doe most shew forth their wise vnderstanding, and whose lips doe vtter the purest knowledge, so as long as they vnderstand and speake as men, are they not faine sundry waies to excuse themselues? (1614 Hooker, p. 5; Traugott and Dasher 2005: 37, ex. 20)

Here the conditional reading is salient, while the temporal meaning is still available. Traugott and Dasher paraphrase the temporal meaning as "for the time that they understand and speak as men”, i.e. "as long as they live”. From the mid-19th century there are examples in which the conditional is the only possible meaning as in (3).

(3) "Would you tell me, please, which way I ought to go from here?"

"That depends a good deal on where you want to get to," said the Cat.

"I don't much care where-" said Alice.

“Then it doesn't matter which way you go," said the Cat.

“- so long as I get somewhere,” Alice added as an explanation. (1865 Carroll, Chapter 6, p. 51; Traugott and Dasher 2005: 37, ex. 21a)

Thus meaning change is the result of the interaction between speakers/writers and addressees/hearers in communicative situations. Speakers/writers use established coded meanings (e.g. the temporal reading of so/as long as) in creative 
ways to invite inferences. Through repeated use, such invited inferences become conventionalized and ultimately they become new coded meanings (Traugott and Dasher 2005: 38).

Thus language change is seen as the result of what Keller (1994) has called an "invisible hand process". Language change comes about as a causal effect of the accumulation of individual speakers' action, who - individually - did not intend this effect.

\section{Pragmatics as the study of performance phenomena}

Performance phenomena pertain mostly to the spoken language, i.e. to language that is produced under the constraints of online production. Such phenomena were shunned as irrelevant for a long time. For historical linguists they were doubly irrelevant. They were irrelevant because they were not part of the language system itself, and they were irrelevant because historical linguists did not have access to the spoken language of the past. The communicative turn in the '70s and '80s of the 20th century turned performance phenomena into legitimate objects of investigation for synchronic linguistics. Pragmaticists focused their attention on transcriptions of spoken interaction. They studied the minutiae of the turn-taking system, the form and function of individual utterances (speech acts), and so on. But these studies were restricted to present-day data. Pragmaticists saw written language as secondary and therefore as uninteresting for pragmatic analyses.

Today performance phenomena have made their way into standard descriptions of the English language (e.g. Biber et al. 1999, who spend a considerable amount of space on such phenomena within the confines of a structural description of the English language), and within the last decade or so, significant progress has been made on the description of performance phenomena from a diachronic perspective. I shall briefly mention three examples which have received a considerable amount of attention from historical pragmaticists, inserts, speech acts and terms of address. To the extent that the analyses of these elements rely on references to social conditions of their use, they clearly go beyond the narrow Anglo-American conceptualization of pragmatics. 


\subsection{Inserts}

Biber et al. (1999: 1082) use the term "inserts" to refer to "stand-alone words which are characterized in general by their inability to enter into syntactic relations with other structures. [...] They comprise a class of words that is peripheral, both in the grammar and in the lexicon of the language". They distinguish nine different types of inserts: interjections (oh, ah), greetings and farewells ( $h i$, hello, goodbye), discourse markers (well, right), attention signals (hey, yo), response elicitors (right?, eh?), response forms (yeah, yep), hesitators (um, er), various polite speech-act formulae (thanks, sorry), and expletives (shit, good grief!). Not all of these are equally amenable to a historical analysis. Biber et al. (1999: 1096-1098) provide some statistics about their distribution in American English and British English conversations, but they do not say anything about their occurrence in written genres. It seems reasonable to assume that some of them are relatively infrequent in the texts that have survived from earlier centuries. While some inserts, such as interjections or discourse markers, have been analyzed in their own right, others, like thanks and sorry, have been investigated in larger contexts of speech act studies of thanking and apologizing (e.g. Jacobsson 2002; Jucker and Taavitsainen 2008b), and expletives have been investigated in the context of the language of insults (e.g. Craun 1997).

Taavitsainen (1995) investigates the form, function, and distribution of exclamations, such as alas, ey, ah, harrow, and $O$ in Late Middle and Early Modern English (see also Hiltunen 2006; Person 2009). Their distribution is clearly genre specific. In the Helsinki Corpus, which was used for the investigation, exclamations were particularly frequent in the genres comedy and fiction. They also occurred in trials and in Bible texts. In other genres they were rare. Exclamations were used more widely and with a broader variety of functions than in Presentday English. They were regularly used as vocatives and as appeals to the addressee. The interjection $O$, for instance, is often prefixed to an exclamatory sentence and it often combines with a vocative as in example (4), which is taken from a sermon.

(4) O my God, my God why haste thou forsaken me? (1614 Hooker, Two Sermons Upon Part of S. Judes Epistle, 1614, p. 7; Helsinki Corpus, Taavitsainen 1995: 453)

Discourse markers have received considerable attention in historical pragmatics. Brinton (1996), for instance, analyzed a broad range of discourse markers, or "pragmatic markers”, as she calls them, including Old English hwæt, Middle 
English gan, and Middle and Early Modern English anon. She is interested not only in the developing discourse functions of these elements but also in the grammaticalization processes that they instantiate. In more recent publications she has added analyses of only (Brinton 1998), I say (Brinton 2005) and I mean (Brinton 2007) (see also Jucker 1997, 2002; Fischer 1998; Brinton 2006).

\subsection{Speech acts}

Speech acts are not easily amenable to historical investigations because the traditional research methods developed for present-day languages cannot be applied to historical data. Originally the concept was developed by philosophers who investigated the nature of speech acts on the basis of careful considerations of what it means to name a ship, to make a promise, to issue a command, to ask a question, or to greet somebody (Austin 1962; Searle 1969). Later, empirical methods, such as discourse completion tests and role-plays, were developed to investigate speech acts and their realizations by different groups of speakers (e.g. Blum-Kulka et al. 1989; Trosborg 1994). For obvious reasons, none of these methods can be applied to historical data.

More recently, corpus-based research methods have been improved and developed to such an extent that various avenues of investigations of historical speech act material have become available. It is, of course, possible to search for verbs denoting specific speech acts. Such speech act verbs are sometimes used performatively to carry out the speech act they denote. Kohnen (2008a), for instance, argues that in Old English explicit performatives were typically used to issue requests and commands as in (5):

(5) Ic bidde eow pæt ze zymon eowra sylfra, swa eowere bec eow wissiað. (Ælfric, Letter to Wulfsige, 26; Helsinki Corpus, Kohnen 2008a: 30)

'I ask you to take care of yourselves, as your books teach you.'

The Old English verb biddan 'ask, bid' is here used performatively. By saying Ic bidde eow 'I ask you' the speaker carries out the speech act of asking or requesting (see in particular Kohnen 2000).

However, many verbs that describe a speech act are not normally used performatively. They are used to talk about the speech act they name. They may occur in narratives with an account that a particular speech act had been performed, or in negotiations when the precise speech act value of an utterance is being discussed. 
(6) If eny man wolde challenge a frere of Seint Frauncessis ordre and seue ... Frere, thou louest money as myche as othere men [...] (c.1449 Pecock Repr.; Taavitsainen and Jucker 2007: 113)

'If any man were to challenge a friar of the order of St. Francis and to say ... "Friar, you love money as much as other men [...]'

In (6) the speech act verb "challenge" is used together with an example of an utterance with this speech act value.

Many speech acts, perhaps most, are carried out without the relevant speech act verb. In order to locate relevant speech acts, the researcher has to rely on the philological method of actually reading the source texts. Jucker and Taavitsainen (2000) have used this method to describe insults in the history of English. But the method obviously precludes any statistical results. The findings can only be very selective based on the available research time.

Some speech acts show recurrent surface patterns. Deutschmann (2003), for instance, has shown that apologies in English are mostly formulaic. They can be traced with corpus-linguistic tools by searching for a small number of expressions that typically occur in apologies, such as sorry, pardon, and excuse together with related and expanded forms. The same method has recently been used to trace apologies (Jucker and Taavitsainen 2008b), promises (Valkonen 2008) and compliments (Jucker et al. 2008).

\subsection{Terms of address}

In the 13th century under the influence from French, English started to use the second person plural pronoun ye not only for two or more addressees but - under certain circumstances - also for one single addressee. Many Indo-European languages still have this distinction between two pronominal forms of address for a single addressee. On the basis of Latin $t u$ and vos, the pronoun choices are usually abbreviated as T and V (Brown and Gilman 1960: 254). The conditions under which one pronoun or the other is chosen have been the object of extensive research in recent years (see, for instance, the volume by Taavitsainen and Jucker 2003). Brown and Gilman (1960) in their seminal article on the topic tried to find a common denominator for all languages with such a system. They argue that this common denominator is the semantics of power and solidarity. In medieval Europe, according to this theory, the power semantics accounted for a nonreciprocal use of $\mathrm{T}$ from the more powerful to the less powerful. The more powerful received $\mathrm{V}$ in return from the less powerful. Equals of the upper classes exchanged mutual $\mathrm{V}$, while equals of the lower social classes exchanged mutual 
T. The power semantics of medieval Europe has been replaced by the solidarity semantics in which mutual $\mathrm{V}$ signals distance and mutual T solidarity.

A significant body of research has shown that social conditions for the choice of $\mathrm{T}$ or V in specific situations are considerably more complex. Mazzon (2000), Honegger (2003), and Jucker (2006), for instance, have shown that Chaucer's system of pronoun choices is much more situationally governed than the usual present-day systems in languages such as German, French, or Italian. In the present-day forms of these languages, choices are more or less fixed for any given dyad of speakers, and a switch from mutual $\mathrm{V}$ to mutual $\mathrm{T}$ is a noticeable event, often accompanied by some kind of ritual (a switch from mutual $\mathrm{T}$ to mutual $\mathrm{V}$, i.e. from informal to formal, would be very unusual). In Chaucer's English, the characters of his fictional work used a more complex system that was based not only on social status between the characters but also on the basis of situational dominance or subjugation. Such approaches have replaced the earlier accounts of Chaucer's use of personal pronouns by such scholars as Nathan (1959), Wilcockson (1980), and Burnley (1983), who tried to explain the choices largely on the basis of fixed social relationships.

By the time of Shakespeare, it does no longer seem possible to provide an account that explains individual pronoun choices. Researchers, therefore, generally focus on frequencies and on co-occurrence patterns of nominal and pronominal terms of address. U. Busse (2002, 2003), for instance, shows that titles of courtesy, such as Your Grace, Your Ladyship, (my) liege, or sir, are more likely to occur together with a $\mathrm{V}$ pronoun than any of the other categories of nominal terms of address, while terms of endearment, such as bully, chuck, heart, joy, or love are most likely to occur together with a T pronoun (see also Stein 2003; B. Busse 2006).

\section{Discourse as dialogue}

Discourse can be seen as a stretch of conversation or as a domain of language. In this section, I will use the term "dialogue" to refer to the former and the term "domain of discourse" for the latter. The terms "discourse" and "dialogue" imply an interaction between a speaker or writer and a recipient. Written texts, although there is no regular exchange of roles between speaker/writer and hearer, do have an addressee, even if the addressee is only a recipient and cannot actively contribute to the interaction. They are what Kilian (2005: 102) identifies as a "functional" dialogue.

Fritz (1995: 469) distinguishes three stages of what he calls "historical dialogue analysis". The first stage is characterized by analysis of the pragmatic 
structure and function of a historical dialogue in its social and historical context. The second stage is characterized by a contrastive comparison of earlier dialogue forms with later dialogue forms. The third and most advanced stage is characterized by an investigation of the evolution and dissemination of specific forms of dialogue.

In the first stage, the researcher can use the same conversation analytical or dialogue analytical tools that are employed in modern data in order to investigate older forms of dialogue. The analysis can either adopt a macro perspective or a micro perspective. Under the macro perspective, the researcher focuses on the structure of the dialogue under analysis. Levinson (1983) reserved the term "discourse analysis" for such macro analyses of dialogue structures. Under the micro perspective, the researcher focuses on individual pragmatic elements, such as greetings, address terms, discourse markers and so on; or on local structures, e.g. adjacency pairs, such as question-answer sequences. Levinson (1983) used the term "conversation analysis" for this type of investigation.

An analysis of individual pragmatic elements in individual dialogues of earlier periods coincides with the pragmatic research interests sketched out above. And indeed, a considerable amount of research has been published, e.g. on address terms in Chaucer's narratives or in Shakespeare's plays (see Section 3.3). But researchers have also adopted the larger perspective of looking at the inventory of pragmatic elements making up a specific type of historical dialogue. Watts (1999), for instance, investigates in detail two dialogues that were printed in 16thcentury English language coursebooks for the benefit of learners of English as a foreign language.

However, in practice it is not always easy to distinguish between the different stages envisaged by Fritz. Jucker and Taavitsainen (2000), for instance, investigate the use of insults in the history of English. The aim is to show a development or an evolution from the earlier forms to the later forms, but at present all that seems to be possible is a contrastive analysis of selected examples at different periods in the history of English. It is not yet possible to trace a continuous evolution of specific speech acts, such as insults. Archer in various publications (e.g. Archer 2005, 2006, 2007) gives a detailed picture of Early Modern English courtroom dialogue and thus carries out research at the first stage of historical dialogue analysis, but she also compares these findings to the present-day courtroom, representing the second stage. And finally she also draws attention to developments within the period under investigation, and thus contributes to stage three of historical dialogue analysis. She focuses mainly on the questionanswer sequences in the courtroom dialogues and uses these to pinpoint the (changing) discursive roles of the active participants in the English courtroom, i.e. the judges, lawyers, witnesses, and defendants. 
Taavitsainen (1999) also investigates the evolution of a particular form of dialogue. She assesses medical dialogues in Late Middle and Early Modern English and traces the evolution of these dialogues between 1375 and 1750. She describes two traditions that are evident in Early English medical dialogues: the scholastic formula, based on the format of debates by Greek philosophers, and the mimetic dialogues, in which material is presented in fictional conversations between the author and the reader or between fictional characters. Taavitsainen shows how these traditions develop over the centuries and how, in the 18th century, medical dialogues merge with the new pamphlet tradition, in which social matters, such as health-care for the poor or polite conversations, are treated.

\section{Discourse as a domain of communication}

As pointed out in Section 1, the term "discourse" can also be used in a more general sense as the totality of linguistic practices that pertain to a particular field of knowledge or to a particular occupation. Such discourses consist not of utterances but of typical text types, characterized by specific lexical items, idiosyncratic syntax, and particular routinized patterns of interaction. In such a context, researchers also ask more general questions about the dissemination of information within groups of speakers. Three such domains of communication in particular have received a fair amount of scholarly attention for the Early Modern English period: courtroom discourse, the discourse of science and news discourse.

\subsection{Courtroom discourse}

A considerable amount of research has appeared on courtroom discourse in the Early Modern English period. The Early Modern English courtroom differed considerably from its modern equivalent. While modern courts presume a defendant to be innocent until proven guilty, the Early Modern courtroom expected the defendants to prove their innocence. Archer (2005: 85) demonstrates how this leads to a more active involvement on the part of the defendant. It was only in the later part of the Early Modern period that courtrooms introduced defence counsels who started to speak on behalf of the defendant.

Koch (1999: 410-411), in his analysis of excerpts of three early Romance court records, draws attention to the communicative complexity of such records. The records written by a court scribe and addressed to a future reader are legal 
documents with appropriate formality of expression especially in the ritualistic elements pertaining to the formalities of the proceedings. These parts of the court records are characterized by the "language of distance" as Koch calls it. Embedded in this formal document there is a transcription of the verbal interaction taking place in the courtroom between the judge, the witnesses, the defendants and the lawyers. These utterances, even if they are written down, are closer to spoken language, or the "language of immediacy". There may even be further embeddings, especially if the court cases dealt with libel, in which courtroom interactants report utterances that were spoken outside the courtroom. Such reported utterances are even closer to the language of immediacy.

In her work on the Early Modern English courtroom Archer $(2005,2006,2007)$ draws a detailed picture of the strategies adopted by the judge, the lawyers, the defendants, and the witnesses. She concludes that the frequency of questions, their function and their interactional success depended on a number of sociopragmatic factors, such as the speech event, the position of the question, and the discursive roles of the speaker and the addressee as well as the date of the trial (2005: 281). Culpeper and Semino (2000) extend the scope of courtroom discourse. They use two types of data, learned treatises on the topic of witchcraft and courtroom witness depositions. In their analysis, they deal with speech act verbs, such as to curse and they show how such verbs could be used to reinterpret trivial arguments within a village community into a witchcraft event.

The witch trials that took place in 1692 in the Puritan village of Salem in the colony of Massachusetts have attracted a considerable amount of research into the discourse strategies adopted by the participants and the functional and structural properties of the trials as such. Kahlas-Tarkka and Rissanen (2007), for instance, investigated the discourse strategies of "successful" and "unsuccessful" defendants in the Salem witch trials, while Hiltunen and Peikola (2007) focus on the material evidence of these trials, i.e. the handwritten records and the printed editions. Their contribution demonstrates vividly how important it is not to forget the communicative role of the scribe who commits the spoken words in the courtroom to writing and thus makes it available for future generations (see also Doty and Hiltunen 2002; Hiltunen 2004; Doty 2007).

\subsection{The discourse of science}

In the late medieval world, the discourse of science was multilingual. The main language for written texts was Latin, but texts started to be translated into the vernacular and the Greco-Roman tradition provided a model for scientific writing in the vernacular. 
In modern linguistics, "medical discourse" refers collectively to the communicative practices of the medical profession, both written and spoken. In the late medieval period, the medical profession consisted of heterogeneous groups of practitioners, including physicians, surgeons, barbers, midwives, itinerant specialists (e.g., bonesetters and oculists), herbalists, apothecaries, wisewomen, and others. They can be roughly divided into clerical and elite practitioners and tradespeople or ordinary practitioners; literacy was restricted mostly to the elite group (Taavitsainen 2006: 688).

Taavitsainen (2006) gives an overview of genres that were important for this discourse community. Compilations and commentaries of earlier studies were important for the dissemination of scholastic knowledge. Texts in question-andanswer format and pedagogical dialogues were also popular genres of scientific and medical writing that were adopted from Latin models into the vernacular. The volume edited by Taavitsainen and Pahta (2004) contains a range of detailed studies of medical and scientific writing in Late Medieval English. Mäkinen (2004), for instance, describes Middle English herbal recipes and recipes in manuals for medicinal plants and shows the textual traditions that link them together.

Valle (1999: vii) takes the view that "science has at least since the seventeenth century taken place within a knowledge-producing discourse community, and that this community will in some way be 'represented' in scientific texts, in forms which can be linguistically identified and studied". The totality of texts produced by this discourse community is, therefore, the discourse of science. In her study, Valle describes the discourse community of the Royal Society on the basis of a corpus of texts drawn from the Philosophical Transaction, spanning the three centuries from the beginning of publication in 1665 to 1965 (see also Valle 1997, 2006). Gotti (2006), too, deals with the discourse community of the Royal Society in London and illustrates some of the methods that were used by this community to spread the news about new discoveries and other scientific findings. Letters exchanged between scholars played an important role. They were not only exchanged between individuals, but they were frequently copied and passed on to new recipients. Some influential scholars at the centre of scientific networks regularly received, sent, and resent a large number of letters and thus had the role of clearing houses.

\subsection{Early English news discourse}

With the invention of the printing press it became possible to publish accounts of recent events and to disseminate them to a large audience. In the 16th and 17th centuries pamphlets and newsbooks were used for this purpose (Raymond 2003). The first newspapers in the modern sense appeared in the early 17th century, first 
on the continent but soon also in England (Brownlees 1999; Studer 2008). The first newspapers or corantos, as they were originally called, consisted mainly of dispatches from correspondents from important places throughout Europe. These letters were inserted into the newspaper in the order in which they arrived at the editorial office in London. There was no other structural principle. It took another century for the first daily newspapers to be published in the early 18th century. As Sommerville (1996) has pointed out, the revolutionary aspect of this kind of news discourse consisted in the fact that newspapers appeared in regular intervals, weekly at first, twice or three times a week later, and then daily. Thus, news was no longer reported in response to important events, but a certain amount of space had to be filled with news on a regular basis.

The early news discourse has attracted a fair amount of research recently not only in collections of articles, such as Ungerer (2000), Herring (2003), Raymond (2006) or Brownlees (2006) but also in monographs. Studer (2008), for instance, develops a larger picture of the development of news discourse on the basis of the Zurich English Newspaper Corpus (ZEN). He argues that news discourse is shaped by such external factors as the historical context and technological innovations. News discourse both adopted and adapted generic conventions; that is to say, it used existing genres, e.g. in the form of the letters from correspondents in the early newspapers, and it transformed and shaped them for its own needs.

\section{Summary and outlook}

It is not possible to draw a principled distinction between historical topics that are treated with pragmatic tools of investigation and those that are treated with discourse analytical tools. Traditionally, those approaches that focus on the interactional and dynamic aspects of language belong to pragmatics while those that focus on the structural aspects of dialogues, conversations or discourses belong to discourse analysis. The application of pragmatic and discourse analytical tools to historical data has uncovered a rich area of investigation and thrown new light on much familiar data.

But a lot still needs to be done. At present, three areas of research appear to be particularly promising. First, the research on the history of speech acts has only just started to attract more than just occasional research efforts. In the volume edited by Jucker and Taavitsainen (2008a) a number of researchers have joined forces to investigate a range of different speech acts in the history of English and to develop the necessary methodologies. Recent advances in corpus technology have made it increasingly possible to locate some speech acts automatically. 
Second, the research of the evolution of forms of dialogue is still in its infancy. Kilian (2005) has presented an introduction into historical dialogue research, in which he develops a detailed typology of historical types of dialogues and some methodologies to investigate a broad range of such dialogues, i.e. dialogues in which speakers and addressees take turns in their roles. Culpeper and Kytö (2010: 2) ask: "what was the spoken face-to-face interaction of past periods like?" in a systematic way and approach this question from various angles. In particular they look at the structure of conversations, at what they call "pragmatic noise", i.e. pragmatic interjections or discourse markers, and social roles and gender in interaction.

And third, the evolution of domains of discourse appears to be a very promising field of research. The existing work on courtroom discourse, the discourse of science and news discourse needs to be continued, and other domains should be tackled. The discourse of religion, for instance, would be an obvious candidate because there is wealth of historical material available consisting of many different text types, such as sermons, prayers, treatises and saints' lives. The compilation at the University of Cologne of a Corpus of English Religious Prose is very likely to be a first significant step in this direction (see Kohnen 2007).

Thus it seems that the new corpora and advances in corpus linguistics have had and are having a considerable impact on historical pragmatics and historical discourse analysis. The cooperation between corpus linguists and historical pragmaticists/discourse analysts has only just started, but it promises considerable advances in our understanding of human interaction and communication from a historical perspective.

Acknowledgments: I thank Thomas Kohnen, Daniela Landert, and Elizabeth C. Traugott for valuable comments on a draft version of this paper. The usual disclaimers apply.

\section{References}

Archer, Dawn. 2005. Questions and Answers in the English Courtroom (1640-1760). Amsterdam/Philadelphia: John Benjamins.

Archer, Dawn. 2006. (Re)Initiating strategies: Judges and defendants in Early Modern English courtrooms. Journal of Historical Pragmatics (Special Issue on Historical Courtroom Discourse, ed. by Barbara Kryk-Kastovsky) 7(2):181-211.

Archer, Dawn. 2007. Developing a more detailed picture of the English courtroom (1640-1760): Data and methodological issues facing historical pragmatics. In: Fitzmaurice and Taavitsainen (eds.), 185-217.

Austin, J. L. 1962. How to Do Things With Words. Oxford: Oxford University Press. 
Biber, Douglas, Stig Johansson, Geoffrey Leech, Susan Conrad, and Edward Finegan. 1999. Longman Grammar of Spoken and Written English. London: Longman.

Blakemore, Diane. 1992. Understanding Utterances. An Introduction to Pragmatics. Oxford: Blackwell.

Blum-Kulka, Shoshana, Juliane House, and Gabriele Kasper (eds.). 1989. Cross-Cultural Pragmatics: Requests and Apologies. Norwood, N): Ablex.

Borgmeier, Raimund, Herbert Grabes, and Andreas H. Jucker (eds.). 1998. Anglistentag 1997 Giessen. Proceedings. Trier: Wissenschaftlicher Verlag.

Brinton, Laurel J. 1996. Pragmatic Markers in English. Grammaticalization and Discourse Functions. Berlin/New York: Mouton de Gruyter.

Brinton, Laurel J. 1998. "The flowers are lovely; only, they have no scent": The evolution of a pragmatic marker in English. In: Borgmeier, Grabes, and Jucker (eds.), 9-33.

Brinton, Laurel J. 2001. Historical discourse analysis. In: Deborah Schiffrin, Deborah Tannen, and Heidi E. Hamilton (eds.), The Handbook of Discourse Analysis, 138-160. Oxford: Blackwell.

Brinton, Laurel J. 2005. Processes underlying the development of pragmatic markers: The case of (I) say. In: Janne Skaffari, Matti Peikola, Ruth Carroll, Risto Hiltunen, and Brita Wårvik (eds.), Opening Windows on Texts and Discourses of the Past, 279-299. Amsterdam/Philadelphia: John Benjamins.

Brinton, Laurel J. 2006. Pathways in the development of pragmatic markers in English. In: Ans van Kemenade and Bettelou Los (eds.), The Handbook of the History of English, 307-334. Oxford: Blackwell.

Brinton, Laurel J. 2007. The development of I mean: Implications for the study of historical pragmatics. In: Fitzmaurice and Taavitsainen (eds.), 37-79.

Brown, Roger and Albert Gilman. 1960. The pronouns of power and solidarity. In: Thomas A. Sebeok (ed.), Style in Language, 253-276. Cambridge, MA: MIT Press.

Brownlees, Nicholas. 1999. Corantos and Newsbooks: Language and Discourse in the First English Newspapers (1620-1641). Pisa: Edizioni ETS.

Brownlees, Nicholas (ed.). 2006. News Discourse in Early Modern Britain. Selected Papers of CHINED 2004. Bern: Peter Lang.

Burnley, David. 1983. A Guide to Chaucer's Language. London: Macmillan.

Busse, Beatrix. 2006. Vocative Constructions in the Language of Shakespeare. Amsterdam/ Philadelphia: John Benjamins.

Busse, Ulrich. 2002. Linguistic Variation in the Shakespeare Corpus. Morpho-Syntactic Variability of Second Person Pronouns. Amsterdam/Philadelphia: John Benjamins.

Busse, Ulrich. 2003. The co-occurrence of nominal and pronominal address forms in the Shakespeare corpus: Who says thou or you to whom? In: Taavitsainen and Jucker (eds.), 193-221.

Craun, Edwin D. 1997. Lies, Slander, and Obscenity in Medieval English Literature. Pastoral Rhetoric and the Deviant Speaker. Cambridge: Cambridge University Press.

Cruse, Alan. 2000. Meaning in Language. An Introduction to Semantics and Pragmatics. Oxford: Oxford University Press.

Culpeper, Jonathan and Merja Kytö. 2010. Early Modern English Dialogues: Spoken Interaction as Writing. Cambridge: Cambridge University Press.

Culpeper, Jonathan and Elena Semino. 2000. Constructing witches and spells: Speech acts and activity types in Early Modern England. Journal of Historical Pragmatics 1(1): 97-116.

Deutschmann, Mats. 2003. Apologising in British English. Umeå: Institutionen för moderna språk, Umeå University. 
Doty, Kathleen L. 2007. Telling tales: The role of scribes in constructing the discourse of the Salem witchcraft trials. Journal of Historical Pragmatics 8(1): 25-41.

Doty, Kathleen and Risto Hiltunen. 2002. "I will tell, I will tell”: Confessional patterns in the Salem witch trials, 1692. Journal of Historical Pragmatics 3(2): 299-336.

Fischer, Andreas. 1998. Marry. From religious invocation to discourse marker. In: Borgmeier, Grabes, and Jucker (eds.), 35-46.

Fitzmaurice, Susan M. and Irma Taavitsainen (eds.). 2007. Methodological Issues in Historical Pragmatics. Berlin/New York: Mouton de Gruyter.

Fritz, Gerd. 1995. Topics in the history of dialogue forms. In: Jucker (ed.), 469-498.

Geis, Michael and Arnold M. Zwicky. 1971. On invited inferences. Linguistic Inquiry 2: 561-566.

Gotti, Maurizio. 2006. Disseminating Early Modern science: Specialized news discourse in the Philosophical Transactions. In: Brownlees (ed.), 41-70.

Herring, Susan C. 2003. Media and language change: Introduction. Journal of Historical Pragmatics (Special Issue on Media and Language Change, ed. by Susan C. Herring) 4(1): 1-17.

Hiltunen, Risto. 2004. Salem, 1692: A case of courtroom discourse in a historical perspective. In: Risto Hiltunen and Shinichiro Watanabe (eds.), Approaches to Style and Discourse in English, 3-26. Osaka: Osaka University Press.

Hiltunen, Risto. 2006. "Eala, geferan and gode wyrhtan": On interjections in Old English. In: John Walmsley (ed.), Inside Old English: Essays in Honour of Bruce Mitchell, 91-116. Oxford: Balckwell.

Hiltunen, Risto and Matti Peikola. 2007. Trial discourse and manuscript context: Scribal profiles in the Salem witchcraft records. Journal of Historical Pragmatics 8(1): 43-68.

Honegger, Thomas. 2003. "And if ye wol nat so, my lady sweete, thanne preye I thee, [...]": Forms of address in Chaucer's Knight's Tale. In: Taavitsainen and Jucker (eds.), 61-84.

Jacobsson, Mattias. 2002. Thank you and thanks in Early Modern English. ICAME Journal 26: 63-80.

Jucker, Andreas H. (ed.). 1995. Historical Pragmatics. Pragmatic Developments in the History of English. Amsterdam/Philadelphia: John Benjamins.

Jucker, Andreas H. 1997. The discourse marker well in the history of English. English Language and Linguistics 1(1): 91-110.

Jucker, Andreas H. 2002. Discourse markers in Early Modern English. In: Richard Watts and Peter Trudgill (eds.), Alternative Histories of English, 210-230. London/New York: Routledge.

Jucker, Andreas H. 2006. "Thou art so loothly and so oold also": The use of ye and thou in Chaucer's Canterbury Tales. Anglistik 17(2): 57-72.

Jucker, Andreas H., Gerd Fritz, and Franz Lebsanft (eds.). 1999. Historical Dialogue Analysis. Amsterdam/Philadelphia: John Benjamins.

Jucker, Andreas H., Gerold Schneider, Irma Taavitsainen, and Barb Breustedt. 2008. Fishing for compliments: Precision and recall in corpus-linguistic compliment research. In: Jucker and Taavitsainen (eds.), 273-294.

Jucker, Andreas H. and Irma Taavitsainen. 2000. Diachronic speech act analysis: Insults from flyting to flaming. Journal of Historical Pragmatics 1(1): 67-95.

Jucker, Andreas H. and Irma Taavitsainen (eds.). 2008a. Speech Acts in the History of English. Amsterdam/Philadelphia: John Benjamins.

Jucker, Andreas H. and Irma Taavitsainen. 2008b. Apologies in the history of English: Routinized and lexicalized expressions of responsibility and regret. In: Jucker and Taavitsainen (eds.), 229-244. 
Kahlas-Tarkka, Leena and Matti Rissanen. 2007. The sullen and the talkative: Discourse strategies in the Salem examinations. Journal of Historical Pragmatics 8(1): 1-24.

Keller, Rudi. 1994. On Language Change. The Invisible Hand in Language. London: Routledge.

Kilian, Jörg. 2005. Historische Dialoganalyse. Tübingen: Niemeyer.

Koch, Peter. 1999. Court records and cartoons: Reflections of spontaneous dialogue in Early Romance texts. In: Jucker, Fritz, and Lebsanft (eds.), 399-429.

Kohnen, Thomas. 2000. Explicit performatives in Old English: A corpus-based study of directives. Journal of Historical Pragmatics 1(2): 301-321.

Kohnen, Thomas. 2007. From Helsinki through the centuries: The design and development of English diachronic corpora. In: Päivi Pahta, Irma Taavitsainen, Terttu Nevalainen, and Jukka Tyrkkö (eds.), Studies in Variation, Contacts and Change in English, Vol. 2. http:// www.helsinki.fi/varieng/series/volumes/02/kohnen/; last accessed 27 June 2017.

Kohnen, Thomas. 2008a. Directives in Old English: Beyond politeness? In: Jucker and Taavitsainen (eds.), 27-44.

Kohnen, Thomas. 2008b. Tracing directives through text and time: Towards a methodology of a corpus-based diachronic speech-act analysis. In: Jucker and Taavitsainen (eds.), 295-310.

Levinson, Stephen C. 1983. Pragmatics. Cambridge: Cambridge University Press.

Mäkinen, Martti. 2004. Herbal recipes and recipes in herbals: Intertextuality in early English medical writing. In: Taavitsainen and Pahta (eds.), 144-173.

Mazzon, Gabriella. 2000. Social relations and forms of address in the Canterbury Tales. In: Dieter Kastovsky and Arthur Mettinger (eds.), The History of English in a Social Context. A Contribution to Historical Sociolinguistics, 135-168. Berlin/New York: Mouton de Gruyter.

Mey, Jacob L. 1998. Pragmatics. In: Jacob L. Mey (ed.), Concise Encyclopedia of Pragmatics, 716-737. Amsterdam: Elsevier.

Nathan, N. 1959. Pronouns of address in the Canterbury Tales. Mediaeval Studies xxi: 193-201.

Person, Raymond R., Jr. 2009. Oh in Shakespeare: A conversation analytic approach. Journal of Historical Pragmatics 10(1): 84-107.

Raymond, Joad (ed.). 2006. News Networks in Seventeenth Century Britain and Europe. London: Routledge.

Raymond, Joad. 2003. Pamphlets and Pamphleteering in Early Modern Britain. Cambridge: Cambridge University Press.

Sommerville, John. 1996. The News Revolution in England. Cultural Dynamics of Daily Information. New York/Oxford: Oxford University Press.

Sperber, Dan, and Ira A. Noveck. 2004. Introduction. In: Ira A. Noveck and Dan Sperber (eds.), Experimental Pragmatics, 1-22. Houndmills: Palgrave Macmillan.

Stein, Dieter. 2003. Pronominal usage in Shakespeare: Between sociolinguistics and conversational analysis. In: Taavitsainen and Jucker (eds.), 251-307.

Studer, Patrick. 2008. Historical Corpus Stylistics. Media, Technology and Change. London: Continuum.

Taavitsainen, Irma. 1995. Interjections in Early Modern English: From imitation of spoken to conventions of written language. In: Jucker (ed.) 439-465.

Taavitsainen, Irma. 1999. Dialogues in Late Medieval and Early Modern English medical writing. In: Jucker, Fritz, and Lebsanft (eds.), 243-268.

Taavitsainen, Irma. 2006. Medical discourse: Early genres, 14th and 15th centuries. In: Keith Brown (ed.), Encyclopedia of Language and Linguistics, 2nd edn., 688-694. Oxford: Elsevier. 
Taavitsainen, Irma and Andreas H. Jucker (eds.). 2003. Diachronic Perspectives on Address Term Systems. Amsterdam/Philadelphia: John Benjamins.

Taavitsainen, Irma and Andreas H. Jucker. 2007. Speech act verbs and speech acts in the history of English. In: Susan M. Fitzmaurice and Irma Taavitsainen (eds.), Methods in Historical Pragmatics, 107-138. Berlin: Mouton de Gruyter.

Taavitsainen, Irma and Päivi Pahta (eds.). 2004. Medical and Scientific Writing in Late Medieval English. Cambridge: Cambridge University Press.

Traugott, Elizabeth Closs. 2004. Historical pragmatics. In: Laurence R. Horn and Gregory Ward (eds.), The Handbook of Pragmatics, 538-561. Oxford: Blackwell.

Traugott, Elizabeth Closs and Richard B. Dasher. 2005. Regularity in Semantic Change. Cambridge: Cambridge University Press.

Trosborg, Anna. 1994. Interlanguage Pragmatics. Requests, Complaints and Apologies. Berlin/ New York: Mouton de Gruyter.

Ungerer, Friedrich (ed.). 2000. English Media Texts Past and Present. Amsterdam/Philadelphia: John Benjamins.

Valkonen, Petteri. 2008. Showing a little promise: Identifying and retrieving explicit illocutionary acts from a corpus of written prose. In: Jucker and Taavitsainen (eds.), 247-272.

Valle, Ellen. 1997. A scientific community and its texts: A historical discourse study. In: BrittLouise Gunnarsson, Per Linell, and Bengt Nordberg (eds.). The Construction of Professional Discourse, 76-98. London/New York: Longman.

Valle, Ellen. 1999. A Collective Intelligence. The Life Sciences in the Royal Society as a Scientific Discourse Community, 1665-1965. Turku: University of Turku.

Valle, Ellen. 2006. Reporting the doings of the curious: Authors and editors in the Philosophical Transactions of the Royal Society of London. In: Brownlees (ed.), 71-90.

Verschueren, Jef. 1987. The pragmatic perspective. In: Marcella Bertuccelli-Papi and Jef Verschueren (eds.), The Pragmatic Perspective: Selected Papers from the 1985 International Pragmatics Conference, 3-8. Amsterdam/Philadelphia: John Benjamins.

Verschueren, Jef. 1999. Understanding Pragmatics. London: Arnold.

Watts, Richard J. 1999. Refugiate in a strange countrey: Learning English through dialogues in the 16th century. In: Jucker, Fritz, and Lebsanft (eds.), 215-241.

Wilcockson, Colin. 1980. Thou and ye in Chaucer's Clerk's Tale. The Use of English 31(3): 37-43. 